\title{
Efficiency measurement of national innovation systems of the European Union countries: DEA model application
}

\section{Eva Jurickova}

Faculty of Management and Economics,

Tomas Bata University in Zlin,

Czech Republic

jurickova@fame.utb.cz

\section{Michal Pilik}

Faculty of Management and Economics, Tomas Bata University in Zlin,

Czech Republic

pilik@fame.utb.cz.

\section{Michael Adu Kwarteng}

Faculty of Management and Economics,

Tomas Bata University in Zlin,

Czech Republic

kwarteng@fame.utb.cr.

Abstract. This paper focuses on measuring technical efficiency of National Innovation System across a sample of the European Union (EU) countries using data envelopment analysis. We used an output-oriented constant returns to scale model to calculate the efficiency of the units represented by the European Union countries. This nonparametric method measures efficiency of input utilisation as compared to the achieved outputs during the consumption process. Following previous studies on this topic, we have used the number of researchers and the expenditures on research and development $(\mathrm{R} \& \mathrm{D})$ as inputs and published scientific journal articles and applied patents as outputs of the model. Stemming from the available data, we have covered the period of 20052016. This period covers the economic period before the financial crisis and economic recession in which it was necessary to use resources effectively for the maximisation of final production. The study also presents data representing the era of growth trend in European economy. The only efficient countries in our study as of 2016 were found to be Cyprus, Luxembourg, Malta, and Romania. The number of efficient units decreased from six countries measured in 2005 from among the eight calculated in the years of the economic crisis to four efficient decision-making units (DMUs) in 2015. Germany, the best performer in the European Union with respect to patent rankings, was classified

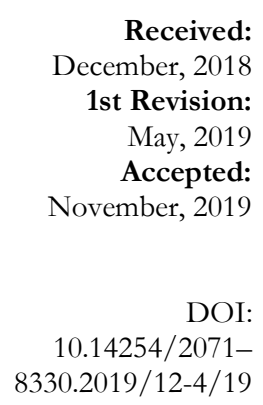

Received:

December, 2018

1st Revision:

May, 2019

Accepted:

November, 2019

DOI:

$10.14254 / 2071$ $8330.2019 / 12-4 / 19$ 
as an inefficient unit with a 0.50 efficiency scale. The results indicate differences between the innovation performance investigated by various indices available in public databases and the DEA technical efficiency. The best performers can be considered as inefficient in the utilisation of resources entering the National Innovation System (NIS) for which technical efficiency is examined in the present study.

Keywords: data envelopment analysis, National Innovation System, technical efficiency, innovation performance.

JEL Classification: O32, O52, O57

\section{INTRODUCTION}

Innovation is considered to be an engine of economy and economic growth. The role of innovation is becoming more important and is one of the key factors for competitiveness (Ivanová \& Čepel, 2018). An inherent part of innovation is appropriate climate for its development; thus, conditions need to be in place to support novel technologies, discoveries, processes and business models (Bouwman, Nikou \& de Reuver, 2019; Ivanová \& Masárová, 2016; Rajnoha \& Lorincová, 2015; Tahrali, Alpkan \& Aren, 2015; Zhu, Xiao, Dong, \& Gu, 2019). The National Innovation System (NIS) can be defined as a network of institutions within public and private sectors with activities and interactions that initiate, import, modify, and diffuse novel technologies (Freeman, 1987). This definition covers all elements of the system and relationships among them. According to Gokhberg and Roud (2016), NIS is understood as a conceptual framework of linkages among the actors whose interactions determine innovation performance. The system itself is aimed at providing a background for innovation development, a legal framework and a network of system elements. Lundvall, Vang, Joseph, and Chaminade (2009) defined NIS as a complex system that is "open, evolving, and encompasses a relationship within and between organizations, institutions and socioeconomic structures". This system is designed to improve innovation, research and development (R\&D) and exploitation of cutting-edge technologies considered sources of entrepreneurship and economic growth. Dahlman (1994) defined NIS at the macroeconomic level as "a network of agents and set of policies and institutions that affect the introduction of technology that is new to the economy". It is critical for economic improvement and represents an important component of economic performance (Dosi, Freeman, Silverberg, \& Soete, 1988; Lööf \& Heshmati, 2006). Within NIS, innovation performance is a result of ideas and creativity used to improve the level of products, processes or services. Innovation efficiency can be interpreted as a ratio of the actual innovation outputs to the invested potential innovation inputs (Hong et al., 2016).

The present paper focuses on efficiency measurement of NIS by means of applying data envelopment analysis (DEA) in the form of an output-oriented constant returns to scale model (CRS). In this study, NIS is represented by the country and its variables entering the system to be transformed into outputs during the innovation process at the macroeconomic level. We have chosen DEA as the key method stemming from our literature review on this topic and the macroeconomic perspective of NIS. Innovation performance of economies is influenced by many factors, especially at the level of government which formulates and defines innovation strategy in its framework along with all other important conditions for innovation development.

Our paper follows previous studies and extends this topic using the data covering the period of 11 years, from 2005 to 2016. We are measuring efficiency of the European Union (EU) member states and 
present the inefficiency level of decision-making units (DMUs) within out sample with improvements of variables entering the national innovation systems.

The present paper is organised as follows: we begin with literature review in section 2 that is focused on NIS and measurement of its efficiency; section 3 describes the methods and variables used; section 4 presents and discusses the main results; and the last section summarises and concludes the paper.

\section{LITERATURE REVIEW ON INNOVATION EFFICIENCY}

To build a theoretical framework, we focused on research that investigated the efficiency of the NISbased non-parametric model. Table 1 provides the studies focusing on the DEA measurement of innovation efficiency among European Union (EU) countries.

Table 1

The DEA measurement of the NIS efficiency among the countries

\begin{tabular}{|c|c|c|c|c|}
\hline Authors (year) & $\begin{array}{l}\text { DEA model } \\
\text { used in the } \\
\text { study }\end{array}$ & Variables & $\begin{array}{l}\text { Number of } \\
\text { countries } \\
\text { examined } \\
\text { in the study }\end{array}$ & $\begin{array}{l}\text { Number } \\
\text { of } \\
\text { efficient } \\
\text { DMUs }\end{array}$ \\
\hline $\begin{array}{l}\text { Rousseau and } \\
\text { Rousseau (1997) }\end{array}$ & \begin{tabular}{|l|} 
CRS output- \\
oriented DEA \\
model
\end{tabular} & $\begin{array}{l}\text { Input: Active population, R\&D expenditures; } \\
\text { Outputs: Number of scientific publications, } \\
\text { number of patents granted by EPO, GDP }\end{array}$ & 18 & 8 \\
\hline $\begin{array}{l}\text { Nasierowski and } \\
\text { Arcelus (2003) }\end{array}$ & $\begin{array}{l}\text { CRS input- } \\
\text { oriented DEA } \\
\text { model }\end{array}$ & $\begin{array}{l}\text { Inputs: Imports of goods and commercial } \\
\text { products, GDP expenditure on research, private } \\
\text { business involvement in R\&D, Employment in } \\
\text { R\&D, expenses in Education; Outputs: external } \\
\text { Patents by resident, patents by residents, national } \\
\text { productivity }\end{array}$ & 46 & 8 \\
\hline $\begin{array}{l}\text { Guan and Chen } \\
(2012)\end{array}$ & $\begin{array}{l}\text { CRS and VRS } \\
\text { input-oriented } \\
\text { DEA model }\end{array}$ & $\begin{array}{l}\text { Inputs: number of full-time equivalent scientists } \\
\text { and engineers, incremental R\&D expenditure } \\
\text { funding innovation activities, prior accumulated } \\
\text { knowledge stock breeding upstream knowledge } \\
\text { production, prior accumulated knowledge stock } \\
\text { participating in downstream knowledge } \\
\text { commercialization, consumed full-time equivalent } \\
\text { labour for non-R\&D activities; Outputs: number } \\
\text { of patents granted by United States Patent and } \\
\text { Trademark Office, international scientific papers, } \\
\text { added value of industries, the export of new } \\
\text { products in high-tech industries }\end{array}$ & 22 & $4 / 12$ \\
\hline $\begin{array}{l}\text { Kontolaimou, } \\
\text { Giotopoulos, and } \\
\text { Tsakanikas (2016) }\end{array}$ & $\begin{array}{l}\text { Bootstrap } \\
\text { DEA model }\end{array}$ & $\begin{array}{l}\text { Inputs: business expenditures on R\&D, human } \\
\text { capital, entrepreneurial capital based on new } \\
\text { technologies; Outputs: intellectual assets, medium- } \\
\text { tech and high-tech exports }\end{array}$ & 28 & 18 \\
\hline Cai (2011) & $\begin{array}{l}\text { CRS output- } \\
\text { oriented DEA } \\
\text { model }\end{array}$ & $\begin{array}{l}\text { Inputs: R\&D expenditures, total R\&D personnel; } \\
\text { Outputs: granted patents (WIPO), number of } \\
\text { scientific articles, high-technology and ICT } \\
\text { services exports }\end{array}$ & 22 & 2 \\
\hline $\begin{array}{l}\text { Matei and Aldea } \\
(2012)\end{array}$ & \begin{tabular}{|l|} 
VRS output- \\
oriented DEA \\
model
\end{tabular} & $\begin{array}{l}\text { Inputs: new doctorate graduates, international } \\
\text { scientific co-publications, public R\&D } \\
\text { expenditures, business R\&D expenditures, public- } \\
\text { private co-publications, PCT patents applications, } \\
\text { community trademarks; Outputs: employment in } \\
\text { knowledge-intensive } \\
\text { activities, medium and high-tech product exports, }\end{array}$ & 31 & 4 \\
\hline
\end{tabular}




\begin{tabular}{|c|c|c|c|c|}
\hline & & knowledge-intensive services exports & & \\
\hline $\begin{array}{l}\text { Carayannis, } \\
\text { Grigoroudis, and } \\
\text { Goletsis (2016) }\end{array}$ & $\begin{array}{l}\text { Multistage } \\
\text { and multilevel } \\
\text { DEA model }\end{array}$ & $\begin{array}{l}\text { Inputs: population with tertiary education, R\&D } \\
\text { expenditures, non-R\&D innovation expenditures; } \\
\text { Outputs: technological (product or process) } \\
\text { innovators, non-technological (marketing or } \\
\text { organisational) innovators, sales of new-to-market } \\
\text { and new-to-firm products }\end{array}$ & 23 & 10 \\
\hline $\begin{array}{l}\text { Pan, Hung, and Lu } \\
\text { (2010) }\end{array}$ & $\begin{array}{l}\text { VRS input- } \\
\text { oriented DEA } \\
\text { model }\end{array}$ & $\begin{array}{l}\text { Inputs: total public expenditure on education, } \\
\text { imports of goods and commercial services, total } \\
\text { expenditure on R\&D, direct investment stocks } \\
\text { abroad, total R\&D personnel nationwide; Outputs: } \\
\text { number of patents granted to residents, number of } \\
\text { partners secured abroad by national residents, } \\
\text { scientific articles published by origin of author }\end{array}$ & 33 & 14 \\
\hline $\begin{array}{l}\text { Chen, } \mathrm{Hu} \text {, and } \\
\text { Yang (2011) }\end{array}$ & $\begin{array}{l}\text { CRS and VRS } \\
\text { output- } \\
\text { oriented DEA } \\
\text { model }\end{array}$ & $\begin{array}{l}\text { Inputs: total R\&D manpower, R\&D expenditure } \\
\text { stocks; Outputs: patents, scientific journal articles, } \\
\text { royalty and licencing fees }\end{array}$ & 24 & 7 \\
\hline
\end{tabular}

Source: Authors' compilation

Rousseau and Rousseau (1997) showed that DEA can be used to measurea country's efficiency. Nasierowski and Arcelus (2003) used a model based on the concept of Pareto-Koopmans efficiency, which converts the minimum possible units of input into the maximum units of output following the DEA to measure the relative efficiency within the sample. The non-parametric method in operation research was applied in studies by Carayannis, Grigoroudis, and Goletsis (2016); Guan and Chen (2012); Matei and Aldea (2012); Pan, Hung, and Lu (2010) and Chen, Hu, and Yang (2011). Kontolaimou et al., (2016) investigated the NIS and its efficiency among European countries and discussed innovation indicators and NIS performance. The study created a typology of 28 European countries based on efficiency scores. The methodology involved DEA modelling, and the datasets of two groups were determined by the countries' innovation performances and the European innovation rankings. The analysis identified seven EU countries as innovation leaders, with higher efficiency of the units with respect to the groups divided based on the development in innovation. Lu, Kweh, and Huang (2014) defined innovation as a key resource for competitive advantage and evaluated NIS economic efficiency using DEA modelling. First, the network DEA production process was developed, and the efficiency of the NIS in 30 countries was subsequently measured. The results indicated that the research and development efficiency of a unit is better than the economic efficiency. The second step focused on an evaluation of intellectual capital via truncated regression. The final results offered steps on how NIS efficiency can be improved. Lee and Park (2005) examined the research and development efficiency of 27 Asian countries, and included technical balance, scientific articles, and patents as outputs. Studies by Kotsemir (2013) and Kou, Chen, Wang, and Shao (2016) showed that DEA modelling can be applied in the form of an input-oriented or output-oriented model. Nasierowski and Arcelus (2012) compared the innovativeness of the years 2005 and 2010 using an input-oriented model, with the view that it is better to control the inputs of countries. Relative efficiency of 22 countries was examined by Sharma and Thomas (2008)using an input-oriented DEA model, with a patent granted to residents as an output, and gross domestic expenditure on R\&D and the number of researchers as inputs. Japan, Slovenia, and South Korea were considered technically efficient; however, the remaining investigated countries were considered only partially efficient. Wang and Huang (2007) applied DEA among 30 countries using an input-oriented form of a non-parametric model, and the findings showed that approximately $50 \%$ of units in the sample were efficient in research and development activities. 
Not only the DEA method can be used for examination of innovation efficiency of the units. Mamedov, Movchan, and Ishchenko-Padukova (2016) presented Okun's law as an alternative method to DEA.Novytskyi (2008) examined aspects of economic cooperation of the country with EU states and its important issues fort the acceleration of economic growth. The measurement of production efficiency can also be used in stochastic frontier analysis or the FDH (free disposable hull) method. The study of Carayannis et al. (2016) presented and confirmed DEA modelling as the most prominent method for combining the innovation factors and calculation of NIS effectiveness.

\section{METHODOLOGY AND DATA USED}

The main objective of the present paper was to examine the efficiency of the NIS of EU countries and compare the efficiency of input utilisation to produce outputs of particular systems. For this measurement, data envelopment analysis was used as a specialised modelling tool for the analysis of the efficiency of homogeneous units. This method is based on practical efficiency of the unit within the analysed group with the possibility of including environmental factors. It is used for measurement of efficiency of banks, research institutions, schools or transport services. DEA modelling is useful for comparison of DMU performance from many different areas, such as in the study of Gružauskas and Grmanová (2018) that analysed bank effectiveness related to number of employees and cost expenditures. The presented results indicated possibilities for how to improve effectiveness of the bank system at the economic level. Kocisova, Gavurova, and Kotaskova (2018) used data envelopment analysis for measurement of agricultural efficiency in EU countries and presented possibilities for how to become effective DMUs.

We considered the EU countries as comparable units in innovation policy under the EU ordinance. The basic framework was validated by the European Parliament after the legislative process as the European strategy for the creation of an innovation-friendly environment for the production of competitive products and services (European Commission, 2018a). Based on the principle of DEA, we understood homogeneous units as countries with the same or equivalent outputs. In the present paper, the production of the units was measured by the number of patent applications collected by the European Patent Office and the number of scientific articles listed in journals classified bythe Scientific Information Science Citation Index (SCI) and Social Sciences Citation Index (SSCI).

Based on information from the literature review, DEAcan be adopted as an appropriate method for the examination and evaluation of the innovation efficiency of EU countries. The principle of DEA modelling is the comparison of a set of units, consideration of the resources used and identification of the most efficient units and inefficient units with improvements. This is possible with defined inputs and outputs. Thus, DEA is a non-parametric model for the measurement of the relative performance within a set of DMUs. Coelli (1996) described the principle of the model as a construction of a non-parametric envelopment frontier over the data points such that all the observed points lie on or below the innovation production frontier. We decided to use the constant returns to scale model when the effective frontier had a conical form. The framework to conduct a relative efficiency within a group of units was developed by Charnes, Cooper, and Rhodes (1978).Called a primary Charnes, Cooper, and Rhodes (CCR) model, it is a basic DEA model that is based on a productive unit that lies in maximisation of its efficiency rate. In the DEA modelling used in the present paper, we understood $n$ EU countries as productive units and DMUs, where each DMU enters $m$ inputs into the NIS of a particular country to produce $S$ outputs that are homogeneous and comparable. DEA modelling focuses on technical efficiency rate. For the purpose of the present paper we defined productive units as:

$$
D M U_{1}, D M U_{2}, D M U_{3}, \ldots, D M U_{n}
$$


The weighted sum of the following inputs and outputs entering the NIS has to be greater than zero:

$$
0<\frac{\sum_{i=1}^{s} u_{i} y_{i q}}{\sum_{j=1}^{m} v_{j} x_{j q}}
$$

where $v_{j}, j=1,2, \ldots, m$ are the weights assigned to the $\mathrm{j}$-th input, and $u_{i}, i=1,2, \ldots, s$ are weights assigned to the outputs.

The primary DEA programming CCR model oriented on outputs can be defined as:

minimize

$$
g=\sum_{j}^{m} v_{j} x_{j q}
$$

subject to

$$
\begin{aligned}
& \sum_{i}^{r} u_{i} y_{i k} \leq \sum_{j}^{m} v_{j} x_{j k} \quad k=1,2, \ldots, n, \\
& \sum_{i}^{r} u_{i} y_{i q}=1, \\
& u_{i} \geq \ni \quad i=1,2, \ldots, r \\
& v_{j} \leq \ni \quad j=1,2, \ldots, m .
\end{aligned}
$$

When we converted this model into liner programming in a matrix form, we formulated the dual CCR model as:

maximize

$$
g=\phi_{q}+\left(e^{T} s^{+}+e^{T} s^{-}\right)
$$

subject to

$$
\begin{aligned}
& X \lambda+s^{-}=x_{q}, \\
& Y \lambda-s^{+}=\phi_{q} y_{q}, \\
& \lambda, s^{+}, s^{-} \geq 0
\end{aligned}
$$

The constant returns to scale (CRS) model is associated with the primary model due to its computational point of view and interpretation of the calculated results. The model considers an innovation unit effective if the optimal value of the objective function in model (4) equals one; that is, $\mathrm{g}^{*}$ $=1$. If the value is greater than one, the selected unit is considered inefficient (Vincová, 2005). The adopted model can measure the average efficiency of innovation units that are represented by EU countries but does not consider the country size of the units within the sample. We implemented the average values of the inputs and outputs over the period of 2005-2016 and analysed the average efficiency of the units representing 28 countries. Table 5 displays the improvements in the units based on the actual values from 2015. The variable $\phi$ indicates that the unit needs to increase its outputs to be efficient. The objective function marks the rate of efficiency, and for the optimal CRS model should be inverted; that is, $f^{*}=1 / \mathrm{g}^{*}$. In light of this fact, we attempted to elucidate how to maximise outputs of the units to become efficient among the reference set as compared with the most efficient unit.

The dataset used in the present study was obtained from the European Eurostat database and the World Bank database for the period of 2005-2016. We wanted to measure the efficiency of the units prior to the economic crisis, during the economic crisis and following the crisis. We monitored the changes in 
the utilisation of resources entering the system presented by the unit. Based on the literature review, we used two input variables and two output variables in the study.

The inputs were represented by the number of researchers in all sectors of performance and R\&D expenditures of the country (Eurostat, 2018a). The first input was the number of researchers counted in a full-time equivalent, which corresponds to one year of work by one person with respect to residency and non-residency of the EU in all sectors of the economy (Eurostat, 2018c). Researchers are one of the basic factors in an innovation system and are the bearers of creativity and knowledge. Innovation is always the result of activities following ideas, so it is appropriate to focus on its effectiveness. We used the full-time equivalent of this variable, one year's work by person. The second input we used was the amount of R\&D expenditure invested into all sectors of a unit's economy, expressed in mil. EUR. It includes investments in industry, government, services, higher education and the non-profit sector.

The output variables were represented by the number of patents submitted to the European Patent Office, as collected by Eurostat (Eurostat, 2018b) and the number of scientific articles published in journals classified by SCI and SSCI indices. The data were collected by the World Bank for the annual year (World Bank, 2018). Patents can be considered as one of the indicators of research and development activities and the highest level of intellectual property rights protection. Research articles and publications provided by the World Bank's database can also be considered as a research result at the national level. The parameters used in the present study are key to the National Innovation System, as shown by previous studies found in the literature search.

\section{RESULTS AND DISCUSSION}

We used DEA modelling to examine the efficiency of the NIS of EU countries. We investigated the required inputs and outputs of the units to become fully efficient, not only to be their best in innovation performance. Performance of the NIS can be measured by various indicators; however, the purpose of the present study was to compare the utilisation of resources with the relevant outputs of the system within the sample of countries. The calculated results indicate a different position of the units in their efficiency versus their performance. The novelty of this paper comes from the application of the non-parametric method to examine the efficiency of EU countries during the period of 2005-2016. The latest completed data required for this analysis for 2017 or 2018 was unavailable.

Table 2 presents the statistical data of the average values of input and output variables during the monitored period of 2005-2016. There was a wide variance in the minimum and maximum values of the units in all sets of variables.

Table 2

Statistics on inputs and outputs in 2005-2016

\begin{tabular}{|l|c|c|c|c|}
\hline & $\begin{array}{c}\text { Total researchers } \\
\text { (FTE) }\end{array}$ & $\begin{array}{c}\text { Research and } \\
\text { development } \\
\text { expenditure (mil. } \\
\text { EUR) }\end{array}$ & $\begin{array}{c}\text { Scientific journal } \\
\text { articles }\end{array}$ & Patent applications \\
\hline Average & 57955.26 & 9132.81 & 20351.13 & 2297.04 \\
\hline Minimum & 667.17 & 45.80 & 202.03 & 15.75 \\
\hline Maximum & 331320.67 & 73264.32 & 97414.14 & 25695.25 \\
\hline Median & 28253.79 & 2301.36 & 10543.13 & 509.46 \\
\hline Standard deviation & 83217.12 & 16130.63 & 27426.60 & 59.71 \\
\hline
\end{tabular}

Source: Authors' calculations

The maximum value presents over 331000 researchers working in the research and development sector of Germany who published 97414 articles in scientific journals. Germany also invested more than 
73 million EUR into its NIS system, as presented in Table 2. The minimum values of the inputs and outputs were reported by Malta.

The development of the inputs is presented in Figure 1. The data was calculated as the average values of the inputs for the particular year. As can be seen, the development of the average number of "total researchers" increased; the calculated minimum was 49.099 researchers in 2005 and maximum 67.505 researchers in 2016. Based on the calculations, this input increased by 37\% during the analysed period. The growth of this indicator points at the importance of the human capital role in a national system of innovation and the need for investments in this area to pursue world development. Data presented in Table 2 indicates inefficiency of DMUs because of R\&D expenditure increase of $50 \%$ compared to NIS performance increase of $16 \%$. The number of published scientific articles increased by $33 \%$.

The value of the "research and development expenditure" also increased from 7.219 mil. EUR in 2005 to 10.910 mil. EUR in 2016. Figure 1shows that the units increased their investments into R\&D by $51 \%$; thus, this input increased almost twice as fast as the value for "total researchers".

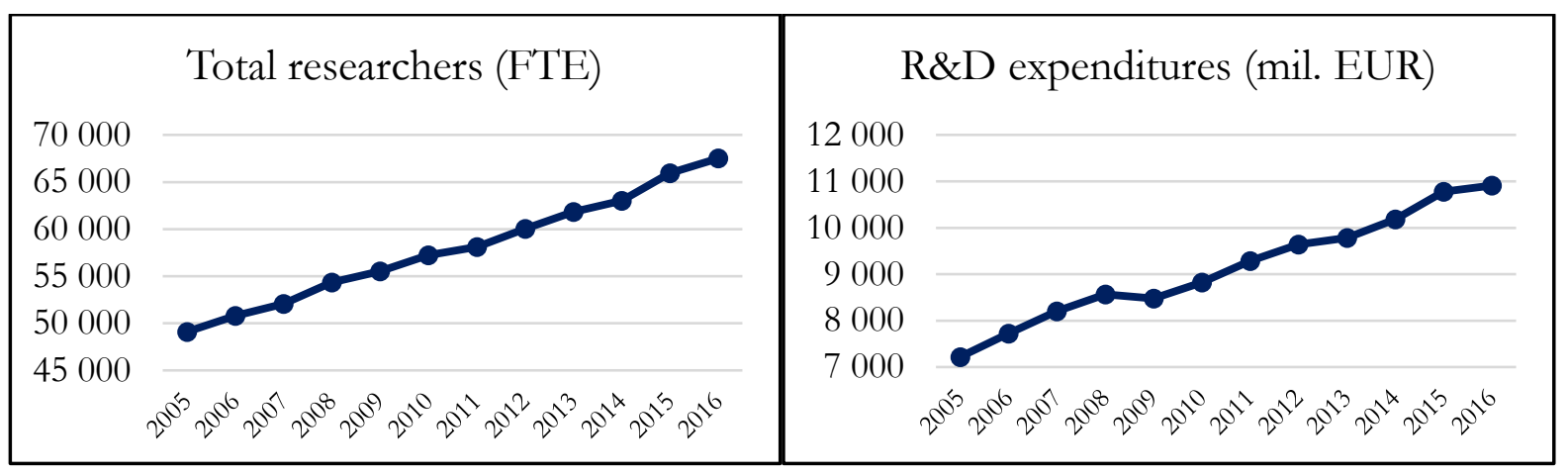

Figure 1. Development of the input variables during the period of 2005-2016

Source: Authors' calculations

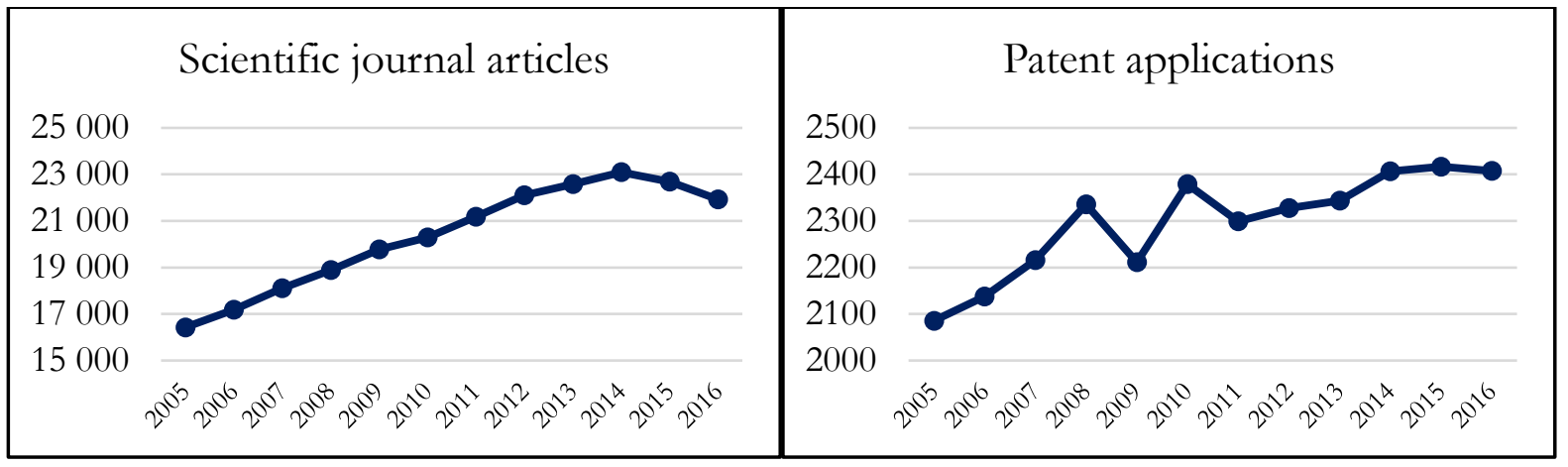

Figure 2.Development of the output variables during the period of 2005-2016

Source: Authors' calculations

The number of published "scientific articles" increased from 2005 to 2014. At the end of the analysed period in 2016, only 21.921 articles were published, which is not in accordance with the increase in input variables during the entire analysed period. The number of "patent applications" increased from 2.085 in 2005 to 2.407 in 2016, with the value being problematic during the economic crisis; we can see a decrease to 2.211 applied patents in 2009. The development was not continual; the graph displays divergences of this indicator. The cause of the decrease can be found in the crisis with the inertia of one or two years. The increase in patent applications of $16 \%$ was not large as was the case with the other 
parameters. An explanation could be the development of demanding technologies brought by the Industry 4.0.

The efficiencies of the units are presented in Table 3. We calculated data using the computer programme available on the D.E.A.O.S. web page. An output-oriented constant returns to scale (CRS) model was used in the present study. We measured the efficiency, focusing on the outputs. This model offers improvements in the output variables when using the values of the inputs. We assumed that the inputs entering the NIS system are allocated and should produce proportionately more outputs to become unit efficient. Based on this, we calculated improvements of the units, as displayed in Table 5.

Table 3

Descriptive statistics of the DEA efficiency during the period of 2005-2016

\begin{tabular}{|l|c|c|c|c|c|c|c|c|c|c|c|c|}
\hline DMUs & 2005 & 2006 & 2007 & 2008 & 2009 & 2010 & 2011 & 2012 & 2013 & 2014 & 2015 & 2016 \\
\hline $\begin{array}{l}\text { Number of } \\
\text { DMUs }\end{array}$ & 28 & 28 & 28 & 28 & 28 & 28 & 28 & 28 & 28 & 28 & 28 & 28 \\
\hline $\begin{array}{l}\text { Number of } \\
\text { efficient DMUs }\end{array}$ & 6 & 6 & 8 & 8 & 6 & 6 & 5 & 4 & 5 & 5 & 4 & 4 \\
\hline $\begin{array}{l}\text { Number of } \\
\text { inefficient } \\
\text { DMUs }\end{array}$ & 22 & 22 & 20 & 20 & 22 & 22 & 23 & 24 & 23 & 23 & 24 & 24 \\
\hline Average & 0.69 & 0.70 & 0.71 & 0.74 & 0.68 & 0.67 & 0.67 & 0.59 & 0.58 & 0.58 & 0.57 & 0.57 \\
\hline Minimum & 0.43 & 0.29 & 0.40 & 0.36 & 0.37 & 0.39 & 0.37 & 0.39 & 0.33 & 0.36 & 0.33 & 0.31 \\
\hline Maximum & 1 & 1 & 1 & 1 & 1 & 1 & 1 & 1 & 1 & 1 & 1 & 1 \\
\hline Median & 0.63 & 0.63 & 0.67 & 0.69 & 0.62 & 0.65 & 0.61 & 0.52 & 0.48 & 0.50 & 0.47 & 0.51 \\
\hline $\begin{array}{l}\text { Standard } \\
\text { Deviation }\end{array}$ & 0.19 & 0.20 & 0.19 & 0.21 & 0.21 & 0.20 & 0.20 & 0.19 & 0.23 & 0.21 & 0.22 & 0.23 \\
\hline
\end{tabular}

Source: Authors' calculations

The average efficiency of the units decreased from 0.69 in 2005 to 0.57 in 2016. This fact is supported by the decreased "number of efficient DMUs". There was a wide variance in the "minimum" and "maximum" values within the sample. The units became inefficient and the "number of inefficient DMUs" increased. This disproportion can be explained by Figure 2 and the values for the outputs. The average calculated efficiency score was unstable and decreased from 0.69 to 0.57 .

Table 4

Efficiency scores of the $28 \mathrm{EU}$ countries

\begin{tabular}{|l|c|c|c|c|c|c|c|c|c|c|c|c|}
\hline & 2005 & 2006 & 2007 & 2008 & 2009 & 2010 & 2011 & 2012 & 2013 & 2014 & 2015 & 2016 \\
\hline Austria & 0.56 & 0.58 & 0.56 & 0.53 & 0.49 & 0.52 & 0.55 & 0.46 & 0.46 & 0.44 & 0.43 & 0.36 \\
\hline Belgium & 0.71 & 0.71 & 0.69 & 0.69 & 0.61 & 0.61 & 0.61 & 0.49 & 0.46 & 0.44 & 0.42 & 0.36 \\
\hline Bulgaria & 1.00 & 1.00 & 1,00 & 1.00 & 0.83 & 0.66 & 0.75 & 0.64 & 0.57 & 0.49 & 0.44 & 0.56 \\
\hline Croatia & 1.00 & 1.00 & 1.00 & 1.00 & 1.00 & 1.00 & 1.00 & 1.00 & 0.94 & 1.00 & 0.91 & 0.85 \\
\hline Cyprus & 1.00 & 1.00 & 1.00 & 1.00 & 1.00 & 1.00 & 1.00 & 1.00 & 1.00 & 1.00 & 1.00 & 1.00 \\
\hline Czech Republic & 0.62 & 0.62 & 0.58 & 0.60 & 0.61 & 0.65 & 0.60 & 0.51 & 0.43 & 0.49 & 0.47 & 0.51 \\
\hline Denmark & 0.54 & 0.56 & 0.55 & 0.47 & 0.42 & 0.48 & 0.53 & 0.43 & 0.46 & 0.48 & 0.46 & 0.38 \\
\hline Estonia & 0.56 & 0.51 & 0.54 & 0.55 & 0.48 & 0.54 & 0.42 & 0.39 & 0.38 & 0.49 & 0.45 & 0.51 \\
\hline Finland & 0.43 & 0.46 & 0.50 & 0.42 & 0.38 & 0.41 & 0.45 & 0.41 & 0.44 & 0.50 & 0.48 & 0.40 \\
\hline France & 0.53 & 0.55 & 0.52 & 0.52 & 0.46 & 0.47 & 0.48 & 0.40 & 0.38 & 0.40 & 0.37 & 0.31 \\
\hline Germany & 0.60 & 0.65 & 0.63 & 0.61 & 0.56 & 0.67 & 0.72 & 0.57 & 0.56 & 0.56 & 0.50 & 0.40 \\
\hline Greece & 0.85 & 0.99 & 0.86 & 0.92 & 0.82 & 0.77 & 0.67 & 0.66 & 0.56 & 0.56 & 0.47 & 0.54 \\
\hline Hungary & 0.68 & 0.61 & 0.59 & 0.66 & 0.50 & 0.44 & 0.40 & 0.39 & 0.33 & 0.36 & 0.34 & 0.38 \\
\hline Ireland & 0.72 & 0.71 & 0.75 & 0.69 & 0.70 & 0.73 & 0.68 & 0.54 & 0.48 & 0.42 & 0.33 & 0.36 \\
\hline
\end{tabular}




\begin{tabular}{|l|l|l|l|l|l|l|l|l|l|l|l|l|}
\hline Italy & 1.00 & 1.00 & 1.00 & 1.00 & 0.87 & 0.81 & 0.78 & 0.68 & 0.59 & 0.62 & 0.57 & 0.50 \\
\hline Latvia & 0.46 & 0.29 & 0.40 & 0.50 & 0.68 & 0.65 & 0.71 & 0.58 & 1.00 & 0.47 & 0.75 & 0.94 \\
\hline Lithuania & 0.64 & 0.62 & 0.53 & 0.87 & 0.61 & 0.58 & 0.55 & 0.48 & 0.41 & 0.42 & 0.47 & 0.55 \\
\hline Luxembourg & 0.50 & 0.64 & 0.83 & 1.00 & 1.00 & 1.00 & 1.00 & 1.00 & 1.00 & 1.00 & 1.00 & 1.00 \\
\hline Malta & 0.46 & 0.63 & 1.00 & 1.00 & 1.00 & 1.00 & 1.00 & 0.59 & 1.00 & 1.00 & 1.00 & 1.00 \\
\hline Netherlands & 1.00 & 1.00 & 1.00 & 1.00 & 1.00 & 1.00 & 0.97 & 0.65 & 0.70 & 0.76 & 0.75 & 0.60 \\
\hline Poland & 1.00 & 1.00 & 0.96 & 1.00 & 0.74 & 0.64 & 0.61 & 0.59 & 0.58 & 0.59 & 0.58 & 0.67 \\
\hline Portugal & 0.51 & 0.53 & 0.44 & 0.36 & 0.37 & 0.39 & 0.37 & 0.42 & 0.47 & 0.52 & 0.50 & 0.50 \\
\hline Romania & 0.63 & 0.56 & 0.66 & 0.89 & 1.00 & 1.00 & 1.00 & 1.00 & 1.00 & 1.00 & 1.00 & 1.00 \\
\hline Slovakia & 0.86 & 0.85 & 0.78 & 0.93 & 0.63 & 0.50 & 0.57 & 0.45 & 0.46 & 0.52 & 0.45 & 0.68 \\
\hline Slovenia & 0.81 & 0.76 & 0.74 & 0.73 & 0.66 & 0.60 & 0.58 & 0.48 & 0.41 & 0.46 & 0.44 & 0.42 \\
\hline Spain & 0.58 & 0.62 & 0.57 & 0.57 & 0.54 & 0.52 & 0.54 & 0.50 & 0.43 & 0.49 & 0.43 & 0.40 \\
\hline Sweden & 0.54 & 0.57 & 0.67 & 0.60 & 0.59 & 0.66 & 0.77 & 0.63 & 0.49 & 0.51 & 0.50 & 0.39 \\
\hline United & 0.61 & 0.62 & 0.61 & 0.62 & 0.56 & 0.53 & 0.53 & 0.46 & 0.37 & 0.39 & 0.35 & 0.32 \\
Kingdom & & & & & & & & & & & & \\
\hline
\end{tabular}

Source: Authors' calculations

The results listed in Table 4 show the efficiencies of the units. If we follow the CRS model, most of the countries were scale inefficient; with the four efficient countries of Cyprus, Luxembourg, Malta, and Romania. Germany was the most powerful country with respect to the number of patents submitted to the European Patent Office (25.012 in 2016), which ranked at the top position of EU countries in statistics of innovation performance worldwide. However, its efficiency scale was 0.50, indicating 18th position among EU countries, which is the same level as Finland and Spain. Cyprus steadily became the most efficient country during the analysed period 2005-2016, which can be explained by effective utilisation of resources to produce appropriate outputs in the form of scientific articles and patent applications. Cyprus submitted 37 patents to the European Patent Office in 2016, at the $23^{\text {rd }}$ position of 28 ranked EU countries.

This difference is based on the principle of the DEA model and shows that the country with the highest number of outputs, classified as the best innovative European country (Germany), can be inefficient and fail to use resources sufficiently to produce effective outputs of the NIS. Sweden is the best country with the highest score of innovation performance (European Commission, 2018b), but with a low efficiency score. The European Innovation Scoreboard considers Sweden as the innovation leader based on the calculated score which consists of several categories. This innovation score doesn't explain the utilisation of the inputs compared to outputs of NIS to become NIS effective.

Table 5 shows the improvements as calculated by DEA to become effective units. The presented data was calculated for 2015 , as this was the latest available.

The improvements were calculated according to the achieved outputs of the units. The data presented in Table 5 explains the efficiency and inefficiency of the units. There were no improvements offered for Cyprus, while Germany needs to double the number of published scientific articles and increase the number of patent applications. The system should be more effective in the production of innovative outputs. France was the most inefficient country, with a 0.31 efficiency scale in 2016; the proposed improvements are to increase the number of "scientific articles" from 69431 to 225998 and "patent applications" from 10559 to 34 370. Investments into research and development are more than 50099 million EUR and need to be reduced to 48835 million EUR assuming the same number of researchers (FTE). 
DMUs and improvements invariables in 2016

\begin{tabular}{|c|c|c|c|c|}
\hline & $\begin{array}{l}\text { Total researchers } \\
\text { (FTE) }\end{array}$ & $\begin{array}{l}\text { Research and } \\
\text { development } \\
\text { expenditures } \\
\text { (mil. EUR) }\end{array}$ & $\begin{array}{l}\text { Scientific journal } \\
\text { articles }\end{array}$ & Patent applications \\
\hline Austria & 45699 to 45699 & 11133 to 8401 & 12366 to 34108 & 2213 to 6104 \\
\hline Belgium & 54280 to 54280 & 10809 to 8830 & 16394 to 45774 & 2155 to 6017 \\
\hline Bulgaria & 16001 to 8140 & 375 to 375 & 2559 to 4537 & 32 to 57 \\
\hline Croatia & 7788 to 7788 & 402 to 402 & 4056 to 4791 & 10 to 61 \\
\hline Cyprus & 898 to 898 & 99 to 99 & 973 to 973 & 49 to 49 \\
\hline Czech Republic & 37338 to 37338 & 2963 to 2963 & 15963 to 31242 & 205 to 1117 \\
\hline Denmark & 44599 to 44599 & 8756 to 7790 & 13471 to 35161 & 2114 to 5518 \\
\hline Estonia & 4338 to 4338 & 270 to 270 & 1482 to 2906 & 54 to 106 \\
\hline Finland & 35908 to 35908 & 5926 to 5926 & 10545 to 26205 & 1818 to 4518 \\
\hline France & 283106 to 283106 & 50099 to 48835 & 69431 to 225998 & 10559 to 34370 \\
\hline Germany & 399605 to 399605 & 92174 to 82681 & 103122 to 255990 & 25490 to 63276 \\
\hline Greece & 29403 to 29403 & 1754 to 1754 & 10725 to 19975 & 100 to 418 \\
\hline Hungary & 25804 to 25804 & 1372 to 1372 & 6208 to 16150 & 94 to 245 \\
\hline Ireland & 19727 to 19727 & 3243 to 2704 & 6834 to 18951 & 593 to 1644 \\
\hline Italy & 133706 to 133706 & 23172 to 16080 & 69125 to 138733 & 4352 to 8734 \\
\hline Latvia & 3152 to 2391 & 110 to 110 & 1257 to 1334 & 15 to 16 \\
\hline Lithuania & 8525 to 7142 & 328 to 328 & 2181 to 3992 & 24 to 44 \\
\hline Luxembourg & 2505 to 2505 & 690 to 690 & 818 to 818 & 581 to 581 \\
\hline Malta & 896 to 896 & 59 to 59 & 320 to 320 & 107 to 107 \\
\hline Netherlands & 81117 to 81117 & 14144 to 14144 & 29949 to 49870 & 7043 to 11728 \\
\hline Poland & 88165 to 88165 & 4112 to 4112 & 32978 to 49372 & 469 to 702 \\
\hline Portugal & 41349 to 41349 & 2388 to 2388 & 13773 to 27462 & 149 to 524 \\
\hline Romania & 18046 to 18046 & 818 to 818 & 10194 to 10194 & 50 to 50 \\
\hline Slovakia & 14149 to 14058 & 641 to 641 & 5359 to 7903 & 41 to 60 \\
\hline Slovenia & 8119 to 8119 & 812 to 812 & 3407 to 8133 & 96 to 377 \\
\hline Spain & 126633 to 126633 & 13260 to 13260 & 52821 to 131612 & 1676 to 6351 \\
\hline Sweden & 70372 to 70372 & 15141 to 13155 & 19937 to 51522 & 3728 to 9634 \\
\hline $\begin{array}{l}\text { United } \\
\text { Kingdom }\end{array}$ & 288922 to 288922 & 40427 to 32826 & 97527 to 308589 & 5313 to 16811 \\
\hline
\end{tabular}

Source: Authors' calculations

The number of published scientific articles and applied patents compared to number of researchers and R\&D expenditures is very low and calculations based on DEA proposes to increase both these indicators. The model proposed the same position of efficiency and possible improvements to the Czech Republic, Poland, Portugal, and other countries. The calculated overall efficiency scores of DMUs in a sample are comparable with previous studies, for example, Carayannis et al. (2016). The study of Pan et al. (2010) presented NIS technical efficiency of European and Asian countries and most of the countries are considered to be effective. It is necessary to analyse inputs and outputs used and analyse NIS in detail.

\section{CONCLUSION}

The aim of the paper was to examine the efficiency of European Union countries and the National Innovation Systems of the 28 units. For measurement, we used data envelopment analysis and an outputoriented constant returns to scale model. The data were obtained from the Eurostat and World Bank databases during the period of 2005-2016. First, we examined the average values of particular variables, 
inputs and outputs. The results of the analysis presented differences between countries in the utilisation of resources entering the NIS as compared with produced outputs. The DEA highlighted the improvements necessary to become an effective unit in innovation technical efficiency. Based on the results of the DEA, we can conclude that the leading innovation countries in the EU are not technically effective. The efficiency scores represent the possibilities for analysis of national innovation systems of the EU countries in detail to discover conditions and factors influencing innovation performance, such as a quality proinnovation environment, educated people working in $\mathrm{R} \& \mathrm{D}$, support of innovation by government and funding of projects.

The results of the study present technical efficiency and inefficiency of the EU member states. Based on the DEA method, the most innovation performed countries are inefficient in the utilisation of the resources entering the system and don't use the inputs effectively. As a result, the outputs in the form of scientific journal articles and patent applications submitted to the European Patent Office need to be increased or R\&D expenditures should be reduced to achieve efficiency of units.

The study is limited by the sample of DMUs and definition of NIS. This basic study needs to be extended with further relevant variables and data. The data provided by Eurostat and World Bank can be a significant limitation for future measurements. The final results are dependent on the data entering the analysis, and it is necessary to compare methodologies and statistical samples to be adequate. The present paper confirms that the expectations and findings of the study are in accordance with previous research and journal articles.

\section{REFERENCES}

Bouwman, H., Nikou, S., \& de Reuver, M. (2019). Digitalization, business models, and SMEs: How do business model innovation practices improve performance of digitalizing SMEs? Telecommunications Policy. Advance online publication.doi:10.1016/j.telpol.2019.101828.

Cai, Y. (2011). Factors affecting the efficiency of the BRICSs' national innovation systems: A comparative study based on DEA and panel data analysis (Economics Discussion Paper No. 2011-52). Kiel, Germany: Kiel Institute for the World Economy.

Carayannis, E. G., Grigoroudis, E., \&Goletsis, Y. (2016). A multilevel and multistage efficiency evaluation of innovation systems: A multiobjective DEA approach. Expert Systems with Applications, 62, 63-80. doi:10.1016/j.eswa.2016.06.017

Charnes, A., Cooper, W. W., \& Rhodes, E. (1978). Measuring the efficiency of decision making units. European Journal of Operational Research, 2, 429-444.

Chen, C. P., Hu, J. L. \&Yang C. H. (2011).An international comparison of R\&D efficiency of multiple innovative outputs: The role of the national innovation system. Innovation, 13 (3), 341-360.

Coelli, T. (1996). A guide to DEAP version 2.1: A data envelopment analysis (computer) program (CEPA Working Paper 96/08). Brisbane, Australia: Centre for Efficiency and Productivity Analysis, University of New England.

Dahlman, C.J. (1994). Technology strategy in East Asian developing countries. Journal of Asian Economics, 5, 541-572.

D.E.A.O.S. DEA Online Software. Retrieved from https://www.deaos.com/login.aspx?ReturnUrl=\%2fprojects.aspx

Dosi, G., Freeman C., Nelson R., Silverberg G., \& Soete, L. (1988). Technological change and economic theory. London: Pinter Publishers.

European Commission. (2018a). Strategy on research and innovation. Retrieved from https://ec.europa.eu/info/researchand-innovation/strategy_en

European Commission. (2018b). European innovation scoreboard 2017. Retrieved from https://ec.europa.eu/growth/industry/innovation/facts-figures/scoreboards_en

Eurostat. (2018a). Intramural R\&D expenditure (GERD) by sectors of performance. Retrieved from http://appsso.eurostat.ec.europa.eu/nui/submitViewTableAction.do

Eurostat. (2018b). Patent applications to the EPO by priority year. Retrieved from http:/ /appsso.eurostat.ec.europa.eu/nui/show.do?dataset=pat_ep_ntot\&lang=en 
Eurostat. (2018c). Total researchers by sectors of performance - full time equivalent. Retrieved from http:/ / ec.europa.eu/eurostat/tgm/table.do?tab=table\&init=1\&plugin=1\&language $=$ en \&pcode $=$ tsc00004

Freeman, C. (1987). Technology and economic performance: Lessons from Japan. London, England: Pinter Publishers.

Gokhberg, L., \&Roud, V. (2016). Structural changes in the national innovation system: Longitudinal study of innovation modes in the Russian industry. Economic Change and Restructuring, 49, 269-288.

Gružauskas, V., \&Grmanová, E. (2018). Efficiency of banks and human resources. Journal of International Studies, 11(2), 193-201. doi:10.14254/2071-8330.2018/11-2/13

Guan, J., \& Chen, K. (2012). Modeling the relative efficiency of national innovation systems. Research Policy, 41, $102-115$.

Hong, J., Feng, B., Wu, Y., \& Wang, L. (2016). Do government grants promote innovation efficiency in China's high-tech industries? Technovation, 57, 4-13.

Ivanová, E., \& Čepel, M. (2018). The Impact of Innovation Performance on the Competitiveness of the Visegrad 4 Conutries. Journal of Competitiveness, Vol. 10, Issue 1, pp. 54-72. doi: 10.7441/joc.2018.01.04

Ivanová, E., \& Masárová, J. (2016). Assessment of innovation performance of Slovak regions. Journal of International Studies, 9(2), 207-218. doi:10.14254/2071-8330.2016/9-2/16

Kocisova, K., Gavurova, B., \& Kotaskova, A. (2018). A slack-based measure of agricultural efficiency in the European Union countries. Journal of International Studies, 11(1), 189-200. doi:10.14254/2071-8330.2018/11$1 / 14$

Kontolaimou, A., Giotopoulos, I., \&Tsakanikas, A. (2016). A typology of European countries based on innovation efficiency and technology gaps: The role of early-stage entrepreneurship. Economic Modelling, 52, 477-484.

Kotsemir, M. (2013). Measuring national innovation systems efficiency - A review of DEA approach (Higher School of Economics Research Paper No. WP BRP 16/STI/2013). Moscow, Russia: National Research University Higher School of Economics.

Kou, M., Chen, K., Wang, S., \& Shao, Y. (2016). Measuring efficiencies of multi-period and multi-division systems associated with DEA: An application to OECD countries' national innovation systems. Expert Systems with Applications, 46, 494-510.

Lee, H. Y., \&Park, Y. T. (2005). An international comparison of R\&D efficiency: DEA approach. Asian Journal of Technology Innovation, 13, 207-22.

Lööf, H., \&Heshmati, A. (2006). Relationship between innovation and economic performance. Economics of Innovation and Technological Change, 15, 317-344.

Lu, W.-M., Kweh, Q. L., \&Huang, C.-L. (2014). Intellectual capital and national innovation systems performance. Knowledge-Based Systems, 71, 201-210.

Lundvall, B.-A., Vang, J., Joseph, K. J., \&Chaminade, C. (2009). Innovation system research and developing countries. In B.-A. Lundvall, K. J. Joseph, C. Chaminade, \& J. Vang (Eds.), Handbook of innovation systems and developing countries: Building domestic capabilities in a global setting (pp. 1-32).Northampton, MA: Edward Elgar.

Mamedov, O., Movchan, I., Ishchenko-Padukova, O., \&Grabowska, M. (2016). Traditional economy: Innovations, efficiency and globalization. Economics and Sociology, 9(2), 61-72. doi:10.14254/2071-789X.2016/9-2/4

Matei, M. M., \&Aldea, A. (2012). Ranking national innovation systems according to their technical efficiency. Procedia - Social and Behavioral Sciences, 62, 968-974.

Nasierowski, W., \&Arcelus, F. J. (2003). On the efficiency of national innovation systems. Socio-Economic Planning Sciences, 37, 215-234.

Nasierowski, W., \&Arcelus, F. J. (2012). About efficiency of innovations: What can be learned from the Innovation Union Scoreboard Index. Procedia - Social and Behavioral Sciences, 58, 792-801.

Novytskyi, V. (2008). Innovation aspects of integration move towards the EU. Journal of International Studies, 1(1), 9-14. doi:10.14254/2071-8330.2008/1-1/1

Pan, T. W., Hung, S. W., \& Lu, W. M. (2010). DEA performance measurement of the national innovation system in Asia and Europe. Asia-Pacific Journal of Operational Research, 27(3), 369-392.

Rajnoha, R., \& Lorincová, S. (2015). Strategic Management of Business Performance Based on Innovations and Information Support in Specific Conditions of Slovakia. Journal of Competitiveness Vol. 7, Issue 1, pp. 3-21. doi: 10.7441/joc.2015.01.01 
Rousseau, S., \& Rousseau, R. (1997). Data envelopment analysis as a tool for constructing scientometric indicators. Scientometrics, 40, 45-56.

Sharma, S., \& Thomas, V. J. (2008). Inter-country R\&D efficiency analysis: An application of data envelopment analysis. Scientometrics, 76, 483-501.

Tahrali, I., Alpkan, L., \&Aren, S. (2015). Effects of generic strategies and environmental conditions on innovation efforts. Journal of Academic Studies, 63(1), 1-30.

Vincová, K. (2005). Using DEA models to measure efficiency. Biatec, 13, 24-28.

Wang, E. C., \& Huang, W. (2007). Relative efficiency of R\&D activities: A cross-country study accounting for environmental factors in the DEA approach. Research Policy, 36, 260-273.

World Bank. (2018). Scientific and technical journal articles. Retrieved from https: / / data.worldbank.org/indicator/IP.JRN.ARTC.SC?end=2016\&start=2011\&view = chart

Zhu, X., Xiao, Z., Dong, M. C., \&Gu, J. (2019). The fit between firms' open innovation and business model for new product development speed: A contingent perspective. Technovation. Advance online publication.doi:10.1016/j.technovation.2019.05.005. 